\title{
ЯВИЩЕ СИНОНІМІЇ В УКРАЇНСЬКІЙ ФАРМАЦЕВТИЧНІЙ ТЕРМІНОЛОГІЇ
}

\author{
ГАЛИНА ХИРІВСЬКА \\ Львівський національний медичний університет імені Данила Галицького, \\ Львів - Україна

\section{ZJAWISKO SYNONIMII W UKRAIŃSKIEJ TERMINOLOGII FARMACEUTYCZNEJ} \\ HAEYNA CHYRIWSKA \\ Lwowski Narodowy Uniwersytet Medyczny im. Daniela Halickiego, \\ Lwów - Ukraina
}

STRESZCZENIE. Artykuł poświęcony jest badaniu synonimii w ukraińskiej terminologii farmaceutycznej. Rozpatrzono zjawisko synonimii w terminologii farmaceutycznej na tle ogólnym. Wyróżniono główne grupy synonimów w analizowanej leksyce terminologicznej.

\section{THE PHENOMENON OF SYNONYMY \\ IN UKRAINIAN PHARMACEUTICAL TERMINOLOGY \\ HALYNA KHYRIVSKA \\ Danylo Halytskyi Lviv National Medical University, Lviv — Ukraine}

ABSTRACT. The article is dedicated to the research of synonyms in the Ukrainian pharmaceutical terminological system in general. The phenomenon of synonyms has been investigated both generally and in the sphere of pharmaceutical terminological system in particular. The main groups of terms synonyms in the mentioned terminological sphere have been determined.

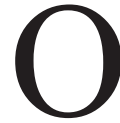

сновним шаром лексики кожної науки чи галузі виробництва є термінологія. Термінологічна лексика має диференційні ознаки, що відрізняють iï від загальновживаної. Серед таких ознак виділимо системність, стилістичну нейтральність, тенденцію до однозначності в межах термінологічного поля, наявність точної дефініції, тенденцію до відкидання синонімів.

Синонімні явища неодноразово були об'єктом вивчення в галузевих терміносистемах. Фармацевтична ж термінологія лише нещодавно опинилася в полі зору науковців і стала об'єктом лінгвістичних досліджень. Наголосимо, що науковці ще не розглядали 111 з огляду на актуалізацію проблеми синонімних зв'язків. У статтях С. Лехніцької ${ }^{1}$ досліджено явище синонімії у фармацевтичній термінології лише на прикладі вибіркових лексичних груп.

До складу фармацевтичної термінології належать назви лікувальних препаратів, рослин, тваринної сировини, латинська хімічна номенклатура і под.

Фармацевтична термінолексика має певні особливості. До іiї складу, окрім саме фармацевтичних термінів, входить частина термінів хімії, ботаніки, фізи-

${ }^{1}$ С. І. Лехніцька, Синонімічні назви у номенклатурі гормональних препаратів, [в:] Studia linguistica, Київ 2009, вип. 2, с. 232-238; С. І. Лехніцька, Синонімні найменування у номенклатурі седативно-снодійних препаратів, [в:] Studia linguistica, Київ 2011, вип. 5, с. 521-526. 
ки, клінічної термінології. У цьому дослідженні залучаємо деякі одиниці вищевказаних терміносистем, оскільки без них неможливе повноцінне функціонування фармацевтичної науки й термінолексики. Значна частина термінів фармації широко вживана серед нефахівців, тому викликає зацікавлення.

У синонімічні зв’язки вступає кожна з названих тематичних груп. Особливу групу термінів-синонімів утворюють назви лікувальних засобів - номенклатура ліків. Ліки-синоніми мають один і той самий список діючих речовин, але різні торговельні найменування. Кожна лікувальна речовина має наукову й тривіальну (від лат. - простий, звичайний) назви.

Новизна цього дослідження полягає в детальному аналізі явища синонімії фармацевтичної термінолексики за ії структурними типами на прикладі термінів різних тематичних груп. Мета статті - описати синонімні відношення в українській фармацевтичній термінології, проаналізувати їхні особливості, з'ясувати причини виникнення синонімії. Предметом студії є види синонімів, їхні структурні групи в межах фармацевтичної термінології. Матеріалом слугувала вибірка, дібрана з Енциклопедичного тлумачного словника фармацевтичних термінів ${ }^{2}$ та Українсько-латинсько-англійського медичного тлумачного словниказ

Синоніми - це, як відомо, слова, що мають тотожне чи близьке значення. Терміни, що виражають одні й ті самі поняття, позначають ті самі предмети та явища дійсності — це іє терміни-синоніми. У загальнолітературній мові синонімія є позитивним явищем, оскільки вона сприяє іiі збагаченню. До синонімії в термінології ставляться неоднозначно. Донедавна превалювала думка, що зазначене явище небажане в терміносистемах. Цю думку підтримують А. Коваль, А. Дяков, С. Толикіна. Названі вчені рекомендують якнайшвидше вилучити всі синоніми 3 терміносистем та уніфікувати їх. Однак у дослідженнях останніх років з'явилася думка, що синонімія - закономірне явище у фахових мовах і без неї аж ніяк не обійтися. В. Даниленко та О. Ахманова стверджують, що „термінні синоніми дуже корисні, оскільки кожен з них по-різному розкриває значення поняття"4. Однак синонімія в термінології має відмінності від синонімії в загальновживаній лексиці, а саме: відсутність експресії, стилістичної і стильової диференціації за сферами використання та ін.

Деякі вчені не визнають існування синонімії в терміносистемах, проте допускають існування термінів-дублетів. На думку А. Коваль, „дублетність це явище глибоко відмінне від загальномовної синонімії. Оскільки термін має свою дефініцію і саме через неї співвідноситься 3 поняттям, він у своїй словесній формі містить певну наперед задану кількість суттєвих ознак цього поняття. Доки визначення поняття не зміниться, словесна форма буде дублетом до попередньої, тобто одиницею з тією ж дефініцією. Тому в межах термінології існують лише терміни-дублети й не існує термінів-синонімів"5.

В. Фаворін акцентував увагу на суттєвій відмінності, що існує між науковими синонімами й термінологічними дублетами. „Кожен синонім вказує на дійсну, хоча й дуже суттєву відмінність між такими об'єктами. Дублети ж завжди позначають той самий об'єкт"6. Л. Симоненко вважає, що синонімію спостерігаємо в термінологічних системах на кожному етапі їхнього розвитку, тому 3 самого початку виникнення терміносистем з'являється потреба у виборі з си-

${ }^{2}$ Енииклопедичний тлумачний словник фармацевтичних термінів, Вінниця 2014.

${ }^{3}$ Украйнсько-латинсько-англійський медичний тлумачний словник, у 2 томах, Львів 1995.

${ }^{4}$ В. В. Турчин, Прагматика наукового терміна, Івано-Франківськ 2004, с. 67.

${ }^{5}$ А. П. Коваль, Практична стилістика сучасної украӥнської мови, Київ 1987, с. 37-38.

${ }^{6}$ В. К. Фаворин, Синонимы в русском языке: Научно-популярный очерк, Свердловск 1953, с. 71. 
нонімічного ряду того терміна, що найточніше охарактеризував би те, чи те поняття, має найбільш інформативну внутрішню форму․

Д. Лотте застерігав, що ,існування двох або кількох термінів на позначення одного поняття приховує небезпеку звуження або розширення семантичної структури одного зі слів" . На його думку, допустимою є лише синонімія, що містить два терміни, один із яких є короткою формою іншого. Учений називає такі терміни парними і вважає їх існування можливим лише за умови їхнього співвідношення з одним поняттям. Деякі науковці вважають абсолютні синоніми нешкідливими. Проте 3 часом в один із цих термінів укладається зміст більш вузький, ніж в інший, або більш широкий, або й зовсім інший. Отже, абсолютні синоніми переважно перетворюються на відносні з усіма недоліками багатозначних термінів 9

Д. Шмельов пише про „відсутність абсолютних меж для синонімів” ${ }^{10}$. Такий підхід до розуміння синонімів дає змогу виявити синонімічні ряди з урахуванням різної близькості значення їхніх компонентів, концептуальної сутності, стилістичних відтінків на рівні функціонування. Б. Головін та Р. Кобрин уважають, що „термінологіям властива саме абсолютна синонімія, а це дає підстави називати зазначене явище термінологічною дублетністю"11.

Дублетність пов'язана 3 інтернаціоналізацією термінології та 3 різними формами мовної економії, згортання, експонента термінологічного знака, має реальні незнищенні підвалини, тому в кожному конкретному випадку питання збереження чи ліквідації дублетності слід вирішувати по-різному. Якщо дублетність надмірна, то іiі справедливо розцінюють як недостатню упорядкованість термінології. Деякі дублетні пари настільки ввійшли в термінологічні системи, що впорядкувати ці системи шляхом усунення одного 3 термінів-синонімів це те саме, що ігнорувати закономірності розвитку мови.

Обов'язково слід ураховувати й усі джерела формування термінів. Більшість $з$ абсолютних синонімів у термінологічній лексиці - це пари слів, одне 3 яких інтернаціональне чи запозичене, а інше - автохтонне. Можливі обидва запозичення з різних мов. Абсолютні синоніми можуть з'являтися і через взаємодію літературної мови та діалектного мовлення.

Ш. Баллі писав: „Слова ніколи не існують самостійно, і нове слово повинно зіткнутися з синонімами й антонімами" 12 . Поява запозичень та новоутворень у кожній терміносистемі суттєво впливає на синонімічні відношення в іiі сфері. Якщо розглядати можливість синонімних зв'язків у композитах і словосполученнях, то слід відмітити, що А. Брагіна ототожнює їх і вважає „цілком синонімічними"13. Н. Клименко називає їх словотвірними дериватами, оскільки складні слова ніби розгортають закладену у відповідний фразеологізм метафору $^{14}$. Більшість дослідників-термінологів (В. Даниленко, В. Молодець, Л. Малевич) також зараховують їх до синонімів.

7 Л. О. Симоненко, Формування украӥнської біологічної термінологїі, Київ 1991, с. 149.

8 Д. С. Лотте, Некоторые принципиальные вопросы отбора и построения научнотехнических терминов, Москва 1941, с. 10.

9 Д. С. Лотте, Основы построения научно-технической терминологии, Москва 1961, с. 158.

${ }^{10}$ Д. Н. Шмелев, Проблема семантического анализа лексики, Москва 1979, с.130.

${ }^{11}$ Б. Н. Головин, Р. Ю. Кобрин, Лингвистические основы учения о терминах, Учеб. пособ. для студ. филол. спец. вузов, Москва 1987, с. 104.

${ }^{12}$ Ш. Балли, Общая лингвистика и вопросы франиузского языка, Москва 1955, с. 28.

${ }^{13}$ А. А. Брагина, Синонимический ряд: Словосочетание-слово, [в:] Новые слова и словари новых значений, Москва 1978, с. 184.

${ }^{14}$ Н. Ф. Клименко, Словотвірна структура і семантика складних слів у сучасній українській мові, Київ 1984, с. 210. 
Упродовж тривалого часу існувала думка, що однокореневі утворення з тим самим значенням $є$ словотвірними варіантами слів (О. Ахманова, О. Смирницький) і між ними не може бути зв'язків синонімічного плану. Якщо проаналізувати зв'язки семантично близьких однокореневих слів, то стає очевидним, що синонімні відношення виявляються й у однокореневих слів ${ }^{15}$.

Т. Панько, І. Кочан, Г. Мацюк розглядають термінологію на функціональному рівні з урахуванням синтагматичних конотацій ${ }^{16}$. На рівні ж парадигматики синонімія існує у вигляді дублетності.

Т. Михайленко справедливо зазначає, що „майже всі вітчизняні та зарубіжні мовознавці визнають природність і неминучість синонімічних відношень між термінами як вияв загальномовних процесів, проте залишаються дискусійними деякі проблеми: з'ясування меж термінологічної синонімії, визначення критеріїв синонімічності в термінології, роль термінів-синонімів, особливості фіксації синонімічних термінів у словниках"17.

Синоніми варто вилучати, проте інколи важко їх позбутися. Наприклад, для точності необхідно створити дуже довгий термін, що $є$ незручним для застосування. У цьому разі до нього підбирають синонім, напр. карбоксиметилцелюлоза - КМЦ.

Хоч явище синонімії $є$ небажаним у термінології, його намагаються уникати, але лінгвістичні розвідки сучасних термінознавців засвідчують активне функціонування синонімів у різних галузевих термінологіях. Отже, воно все-таки існує.

Не становить винятку й обрана для цього дослідження термінолексика. У термінології фармацевтичної галузі теж існує достатньо велика кількість синонімів. Отже, поділимо всі синоніми на:

1) терміни-дублети (з'являються через запозичення відповідників і паралельно в мові використовують запозичене й питоме слово-термін). Термінологічні синоніми (дублети) мають такі різновиди:

а) різні іншомовні слова;

б) іншомовне й національне слово;

в) синонімія на рівні словосполучень.

2) терміни - структурні синоніми (однослівні та словосполучення, паралельне вживання термінів-словосполучень).

3) використання термінів повної та короткої форми (скорочення засобами словотвору, повна форма та абревіатура).

Усі терміни-синоніми, що обрані для аналізу, засвідчують наявність синонімних термінів фармацевтичної галузі в кожній із вищезазначених груп. Аналіз фактичного матеріалу дає підстави виділити такі структурні типи термінівсинонімів фармації, коли в синонімні зв'язки вступають:

1) два слова: аутоінфекиія - самозараження, базовий - нормативний, бактерицидний - бактеріоцидний, целюлоза - клітковина, речовина - сполука, екстракт - витяг, витяжкка, жовчний - біліарний, назальний — носовий, вакуум — насос, водень - гідроген, вуглеводи - карбогідрати, вуглеиь — карбон, флакон — крапельниия, гнильний - іхорозний, диспергування - подрібнення тощо;

2) слово та словосполучення: олеовітамін - риб'ячий жир, иіанобактерї-синьозелені водорості, аскомічети - сумчасті гриби, первомур - кисло-

${ }^{15}$ I. М. Кочан, Варіанти і синоніми термінів з міжнародними компонентами, [в:] „Вісник Національного університету „Львівська політехніка”, сер. „Проблеми української термінології”, Львів 2008, № 620, с. 14-19.

${ }^{16}$ T. І. Панько, I. М. Кочан, Г. П. Мацюк, Украӥнське термінознавство, Львів 1994.

${ }_{17}^{17}$ Т. Д. Михайленко, Синонімічні відношення в украйнській науково-технічній термінології, [в:] „Українське мовознавство”, 2003, № 25, с. 24. 
та надмурашина, фітопрепарат - препарат із рослинної сировини, бактерин - бактеріальна вакцина, блістер - упаковка контурна чарункова, брї- етери поліоксіетиленалкілу, вазодилататори — препарати судинорозширювальні, антипіретики - препарати жарознижувальні, адреноблокатори - препарати адреноблокуючі, адренолітики - препарати адреноблокуючі, адреноміметики - препарати адреноміметичні, анальгетики - препарати знеболювальні, вазопресин - гормон антидіуретичний, арени — вуглеводні ароматичні, алкіни - вуглеводні ацетиленові, алкадієни - вуглеводні дієнові, алкени - вуглеводні етиленові, алкадієни - дієнові вуглеводні, алкани - насичені вуглеводні, протеїди - складні білки, алкени - етиленові вуглеводні, карденоліди - серцеві глікозиди, аеросил - оксид кремнію, алкіни - ацетиленові вуглеводні тощо;

3) слово і два словосполучення: волокна харчові - клітковина харчова, волокна дієтичні; гіалуронідаза — фактор поширення, фактор Дюран-Рейнальса; етанол - спирт вторинний, спирт етиловий тощо;

4) терміни-словосполучення та терміни-епоніми: ичикл Корі, Кребса цикл трикарбонових кислот, нефрокальциноз лікарський - синдром Бернетта, баџила Коха - мікобактерія туберкульозу, гіпотиреоз - хвороба Галла тощо;

5) два терміни-словосполучення: вуглецьь активований - вугілля активоване, фармацевтичний препарат — лікарський препарат, розчин плазмозамінюючий - розчин фізіологічний, насіння чилібухи - блювотний горіх, кислота янтарна - кислота бурштинова, діоксид колоїдний - аморфний діоксид кремнію, препарати антибактеріальні — препарати протимікробні, препарати антибластомні - препарати протипухлинні, препарати антивірусні - препарати противірусні, препарати антигельмінтні — препарати протиглисні, препарати антигіпертензивні - препарати гіпотензивні, препарати анти конвульсивні - препарати протисудомні, препарати нейролептичні — препарати антипсихотичні, препарати гемо статичні — препарати кровоспинні, препарати гіпнотичні - препарати снодійні, препарати гіпоглікемічні — препарати протидіабетичні, препарати десенсибілізуючі - препарати протиалергійні, препарати діуретичні — препарати сечогінні, препарати імунодепресивні - препарати імуносупресивні, препарати протизгортальні - антикоагулянти, препарати седативні - препарати заспокійливі, препарати серцево-судинні — препарати кардіологічні тощо;

6) словосполучення та абревіатура: Біологічно активні добавки - БАД, біологічно активна речовина - БАР, аденозиндифосфат - АДФ, активний фармацевтичний інгредієнт - АФІ, натрію карбоксиметилцелюлоза - натрій КМЦ тощо;

7) назви вітамінів (хімічні назви та їхні словесно-буквенно-цифрові відповідники): Ніацин - вітамін РР, піридоксин - вітамін В6, холін - вітамін В4, кальцифероли - вітамін Д, кобаломін - вітамін В12, рутин - вітамін $P$, карнітин - вітамін B1, кислота пантотенова - вітамін $B$ тощо;

8) низка синонімів, серед яких 4 словосполучення, 1 слово та абревіатуpa: Активний фармачевтичний інгредієнт (АФI) синоніми: активна речовина, діюча речовина, лікарська речовина, субстанція тощо;

9) номенклатура ліків: iї функціонування проілюструємо на прикладі назви ліків амброксол: хлор гідрат транс-4-[(2-аміно-3, 5-дибромбензил)аміно] цчиклогексанолу (амброксолу гідрохлорид) — хімічна назва; амброксол (діюча речовина) - міжнародна назва. Як бачимо, наукова назва відображає склад і молекулярну структуру хімічної сполуки, тому вона є дуже важливою, особливо в процесі виробництва. Користуватися такими назвами досить важко. Саме тому в лікарській практиці надають перевагу не науковим, а популярним, спрощеним назвам. 
До тривіальних назв можуть належати три групи:

1) загальні або вільні найменування;

2) міжнародні непатентовані найменування;

3) товарні знаки.

Загальні найменування вважають єдиними офіційними найменуваннями для лікувальних засобів, що входять до національної або регіональної фармакопеї. Міжнародні непатентовані найменування відбирає й рекомендує Всесвітня організація охорони здоров'я. Товарний знак використовують для розрізнення готових лікувальних засобів, що випускаються різними підприємствами. Кожне таке найменування є міжнародним словесним індикатором лікувальої речовини.

Поряд із товарним знаком (торговим найменуванням) на етикетці або в анотації подають міжнародне непатентоване найменування, що дає змогу ідентифікувати лікувальну речовину, приховану під різними товарними знаками ${ }^{18}$, напр., діючою речовиною в ліках амбробене, амброксол, лазолван, медовент, мукосольван є амброксолу гідрохлорид. Покази для застосування кожного з препаратів, а також їхні фармакологічні властивості або дуже близькі, або ідентичні. Кожен $з$ цих препаратів належить до групи муколітиків. Сдина відмінність у характеристиках ліків - країна-виробник, зокрема амбробене виготовляють у Німеччині, амброксол - у Польщі, мукосольван - у Німеччині, лазолван у Греції, медовент - на Кіпрі.

Абактал, пефлоксацин, пелокс, перти, перфлокс, пефлоцин - низка назв медичних препаратів, які об'єднує пефлоксацин. Пропоновані препарати мають широкий спектр антимікробних дій, бактеріоцидні властивості.

Синоніми до назви препарату амброгексал — це амброксол, амбробене, амбросан, лазолван.

Синонімними до назви нейролептика азалептин є клозапин, алемоксан, лепонекс, до складу яких теж входить клозапін; усі згадані препарати мають хімічну назву 8-хлор-11-(4метил-1-пиперазініл)-5Н-дибензо[b, е][1, 4]діазепін.

Отже, на підставі аналізу фармацевтичної термінології можемо стверджувати, що синонімія є поширеним явищем, що потребує уваги з боку науковців. Зазначимо, що в синонімічні зв'язки вступають різні за структурою терміни.

Синоніми - наслідок лінгвістичних та екстралінгвальних чинників. В Україні, як і в інших країнах світу, у торговій мережі з'являються готові лікувальні засоби з однією і тією ж активною речовиною під кількома комерційними назвами. А це не що інше, як одна 3 причин появи синонімів. Термінисиноніми різняться часом своєї появи й різними джерелами запозичення. Останнє пов'язане з виникненням нових ліків, прогресом фармації.

Функціональний підхід до проблеми мовної синонімії обумовлює існування стилістичних синонімів, що розрізняються сферами вжитку, тому наявність синонімії в обраній для аналізу термінології $є$ природним виявом розвитку мови, хоч іноді це ускладнює процес розуміння тих чи тих понять у межах однієї терміносистеми.

Таким чином, синонімія в термінології фармацевтичної галузі зумовлена неуніфікованістю термінології, постійним розвитком науки й необхідністю якнайточніше назвати відповідний препарат, фактом паралельного використання запозиченого та автохтонного термінів, мовною економією — надання переваги коротким формам, а також чинником співіснування наукової і популярної назв.

${ }_{18}$ М. Н. Чернявський, Латинський язык $и$ основы фармацевтической терминологии, Москва 1984, с. 68. 